\title{
BCL11A wt Allele
}

National Cancer Institute

\section{Source}

National Cancer Institute. BCL11A wt Allele. NCI Thesaurus. Code C97395.

Human BCL11A wild-type allele is located in the vicinity of 2 p16.1 and is approximately $102 \mathrm{~kb}$ in length. This allele, which encodes B-cell lymphoma/leukemia 11A protein, plays a role in both lymphopoiesis and cell shape. Overexpression of the gene is associated with a translocation $\mathrm{t}(2 ; 14)(\mathrm{p} 13 ; \mathrm{q} 32.3)$ as well as chronic lymphocytic leukemia and other B-cell malignancies. 